\title{
Analysis of Sedimentary Environment and Sequence Stratigraphy of Middle-Late Permian Sediments in Coastal Fars, Iran (Zireh Gas Field, Well ZH-A)
}

\author{
Nasser Rezavand ${ }^{1}$, Davood Jahani', Hossein Asilian² \\ ${ }^{1}$ Department of Geology, North Tehran Branch, Islamic Azad University, Tehran, Iran \\ ${ }^{2}$ Department of Stratigraphy and Sedimentology, NIOC Exploration, Tehran, Iran \\ Email: *Rezavand_n@yahoo.com
}

How to cite this paper: Rezavand, N., Jahani, D. and Asilian, H. (2016) Analysis of Sedimentary Environment and Sequence Stratigraphy of Middle-Late Permian Sediments in Coastal Fars, Iran (Zireh Gas Field, Well $\mathrm{ZH}-\mathrm{A})$. Open Journal of Geology, 6, 15391552.

http://dx.doi.org/10.4236/ojg.2016.612109

Received: November 24, 2016

Accepted: December 17, 2016

Published: December 20, 2016

Copyright $\odot 2016$ by authors and Scientific Research Publishing Inc. This work is licensed under the Creative Commons Attribution International License (CC BY 4.0).

http://creativecommons.org/licenses/by/4.0/

\section{Abstract}

The current paper is focused on the facies, sedimentary environment and depositional cycles study of the Middle-Late Permian sediments in the South Fars Zireh Gas Field, the subsurface section of well ZH-A. Four hundred thin-sections obtained from cores and cuttings were examined under standard petrographic microscope. For this study research, Corel Draw X6, Corel Photo-Paint, DN2 Microscopy Image Processing System, Scope Photo, Autodesk Map, Geocalc and Auto Cad 2014 were utilized. Based on microfacies analysis and significant founa and flora, fourteen major facies in four facies associations comprising tidal flat (A), lagoon (B), shoal (C) and open marine (D) identified in the well $\mathrm{ZH}-\mathrm{A}$. This formation was deposited in inner part of a homoclinal ramp. Based on depositional cycles, seven main $3^{\text {rd }}$ order sequences were revealed in the Well $\mathrm{ZH}-\mathrm{A}$. The ooid grainstone facies with interparticle and oomoldic porosity has high reservoir potential. The diagenetic processes like dolomitization and dissolution have significant effect in the reservoir quality. Based on research results, a major framework can be weaved and used to correlate reservoir layering.

\section{Keywords}

Middle-Late Permian Sediments, Depositional Cycles, Homoclinal Ramp

\section{Introduction}

The Middle-Late Permian Dalan Formation is an economically significant gas and condensate reservoir in the Fars region of southwest Iran. This formation overlies the 
Faraghan Formation and conduces to the Kangan Formation. This formation consists of limestone and dolomite accompanied by some evaporite intervals with an overall thickness of $815 \mathrm{~m}$. Edgell [1] has divided the mentioned formation into three members containing: 1) Lower Dalan Member, 2) Nar Evaporite Member and 3) the Upper Dalan Member. The geographical coordinates of the studied subsurface section are $51^{\circ} 56^{\prime} 57.83^{\prime \prime} \mathrm{E}$ and $28^{\circ} 10^{\prime} 23.82^{\prime \prime} \mathrm{N}$ and overlie Zireh anticline which is located about 169 $\mathrm{km}$ from Shiraz city (Figure 1 ).

\section{Methodology}

Four hundred thin-sections obtained from cores and cuttings were examined under standard petrographic microscope. Carbonate rocks were classified using textural classification proposed by Dunham [2]. Diagnostic microfacies criteria of Flügel [3] were used in detecting the microfacies types in carbonate rocks. Evaluation of vertical and lateral changes accomplished according to [4] [5] [6]. Sequence Stratigraphy concepts developed by previous workers (e.g., [7]-[12]) were extended to the current study.

\section{Facies Classification}

\subsection{Facies Association A (Tidal Flat Facies)}

\subsubsection{Facies A1 (Massive to Layered Anhydrite)}

The facies A1 consists of high percent anhydrite (about 80 percent) with divers forms such as nodular and bladed types (Figure 2(a)). This facies formed in supratidal environments due to dry and intense evaporation condition [13] [14] [15] and is mostly developed through the Nar Member.

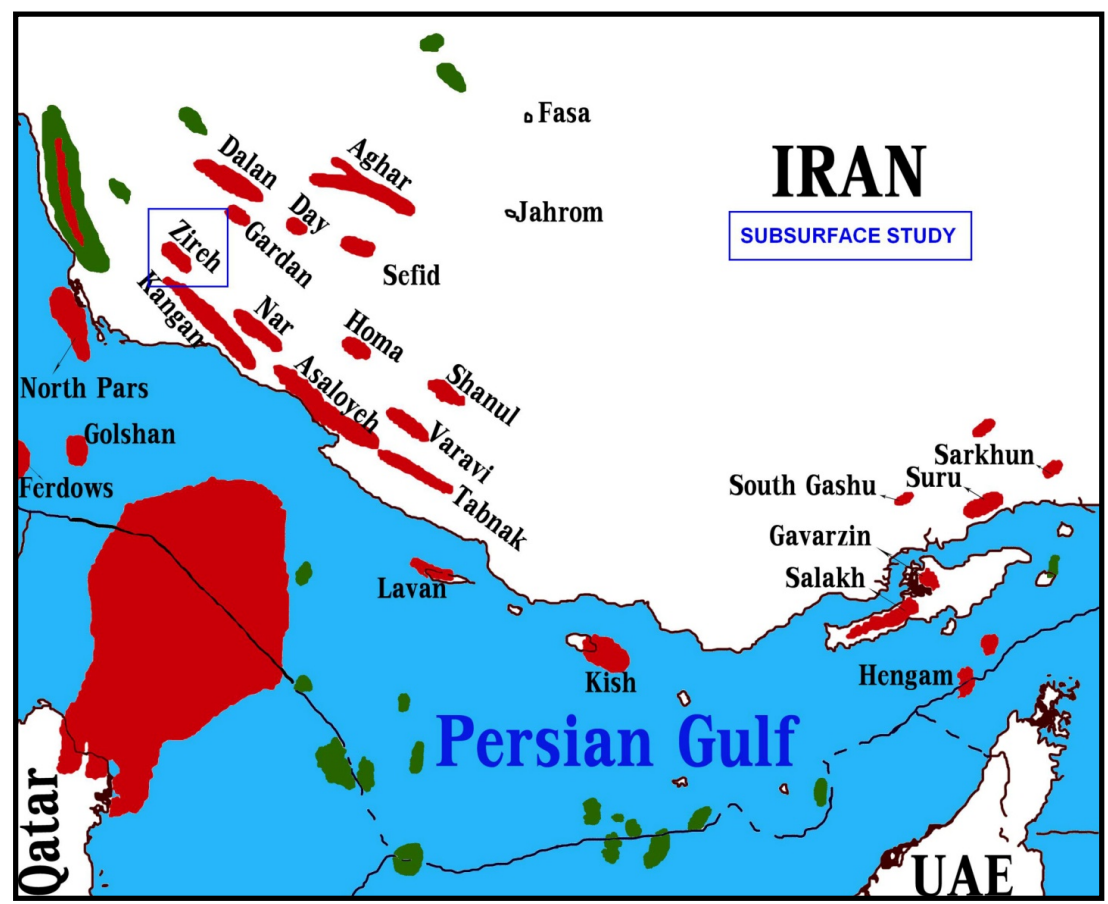

Figure 1. Well ZH-A overlies Zireh Anticline in Coastal Fars Area. 



Figure 2. Tidal Flat Facies: (a) Massive to layered anhydrite with mosaic fabric; (b) Brecciated dolomudstone cemented by anhydrite; (c) Non burrowed mudstone; (d) Facies A4, evaporite casts " $\mathrm{A}$ " are seen in dolomitic mudstone; (e) Peloid intraclast packstone, Intraclasts "I" accompanied by peloids " $\mathrm{P}$ " (XPL).

\subsubsection{Facies A2 (Brecciated Dolomudstone)}

This facies includes angular lithoclasts (often mud clasts) sized of 100 to $800 \mu \mathrm{m}$. The matrix consists of micrite and is associated with rare anhydritic cement (Figure 2(b)). These brecciated dolomudstones represent evapo-karstic and karstic zones that have undergone evaporite and carbonate dissolution resulting in small vugs, dissolution seams and brecciation collapse. They can occur in both shallow-water limestone and evaporites sequences, and mark the top of the low-frequency regressive cycles [4].

\subsubsection{Facies A3 (Non Burrowed Mudstone)}

The facies A3 comprises nonfossiliferous mudstone without bioturbation and lagoonal 
fauna. Oil stains associated with filled fractures occur in some samples (Figure 2(c)). The upper parts of intertidal settings in arid condition practice high salinity and intense evaporation which restrict the activity of browsers and burrowers. The upper intertidal pond is an environment where this facies is formed [5].

\subsubsection{Facies A4 (Dolomitic Mudstone with Evaporite Casts)}

The Facies A4 contains dolomitic mudstone with anhydrite nodules and crystals with fan type, bladed and needle fabrics (Figure 2(d)). This facies has formed in intertidal setting with attention to rare fossils, sparse anhydrite casts and fine-grained dolomites [3] [5].

\subsubsection{Facies A5 (Peloid Intraclast Packstone)}

It consist high percent of intraclasts $(100 \mu \mathrm{m}-1 \mathrm{~mm})$ and few amount of peloids sized of $50-150 \mu \mathrm{m}$. The matrix includes micrite and spary cement, but anhydrite cement is also found (Figure 2(e)). The generation of intraclasts is common in the supratidal and intertidal environments [3] [5]. This facies seems to be developed in tidal channel sites at the adjacency of facies A4.

\subsection{Facies Association B (Lagoonal Facies)}

\subsubsection{Facies B1 (Ooid Wackestone/Packstone with Micritic Ooids)}

It contains of $30 \%-50 \%$ ooid sized of $100-300 \mu \mathrm{m}$ associated with peloids. Ooids are commonly superfecial with one lamina, and micritic nuclei. Cementation and dissolution are more abundant diagenetic features. Dissolution of micrite developed in early stage of diagenesis under influence of meteoric waters, and anhydrite plugging befell in later steps (Figure 3(a)). The micritic ooids with one lamina are contemplated as type 4 ooids which develop in brakish protected lagoons [16]. In carbonate ramps, ooids are common in shorelines or sand shoals [3]. With attention to ooid type and adjacency with tidal flat facies, theses ooids are considered to be deposited in protected lagoons near the shoreface.

\subsubsection{Facies B2 (Peloid Wackestone/Packstone)}

The facies B2 includes more than $30 \%-50 \%$ peloids sized of $50-300 \mu \mathrm{m}$ with good sorting and roundness. The benthic forams, dasyclads and fusulinids are uncommon (Figure 3(b)). With respect to the angular peloids, we can consider them as rounded micritic intraclasts [3] [17]. Considering the peloid types, infrequent skeletal particles and non attendance subaerial exposure features, this facies is attributed to restricted lagoonal settings with hypersaline condition [3] [18].

\subsubsection{Facies B3 (Bioclast Wackestone/Packstone with Algal and Benthic Foraminifera)}

This facies contains calcareous green algae such as Mizzia sp. and Permocalculus $s p$. and benthic foraminifera (such as Hemigordius sp. and Geinitzina sp.) accompanied by gastropods, ostracods, echinoderms and bivalves. There is no spary cement and the oil show is rarely found (Figure $3(\mathrm{c})$ ). The lagoonal setting is a place that this facies is 
formed [3] [19].

\subsubsection{Facies B4 (Mudstone with Lagoonal Foraminifera)}

This facies consist of lagoonal foraminifera such as Longa sp. and Dagmarita sp. sized of $250-500 \mu \mathrm{m}$. The matrix only includes micrite and bioturbation and burrowing are uncommon (Figure 3(d)). Micritic matrix, low diversity and present fauna, denotes a quiet-water lagoonal environment [3].

\subsubsection{Facies B5 (Bioclast Wackestone/Packstone with Gastropod)}

The facies B5 comprises high percent of gastropods associated with foraminifera and
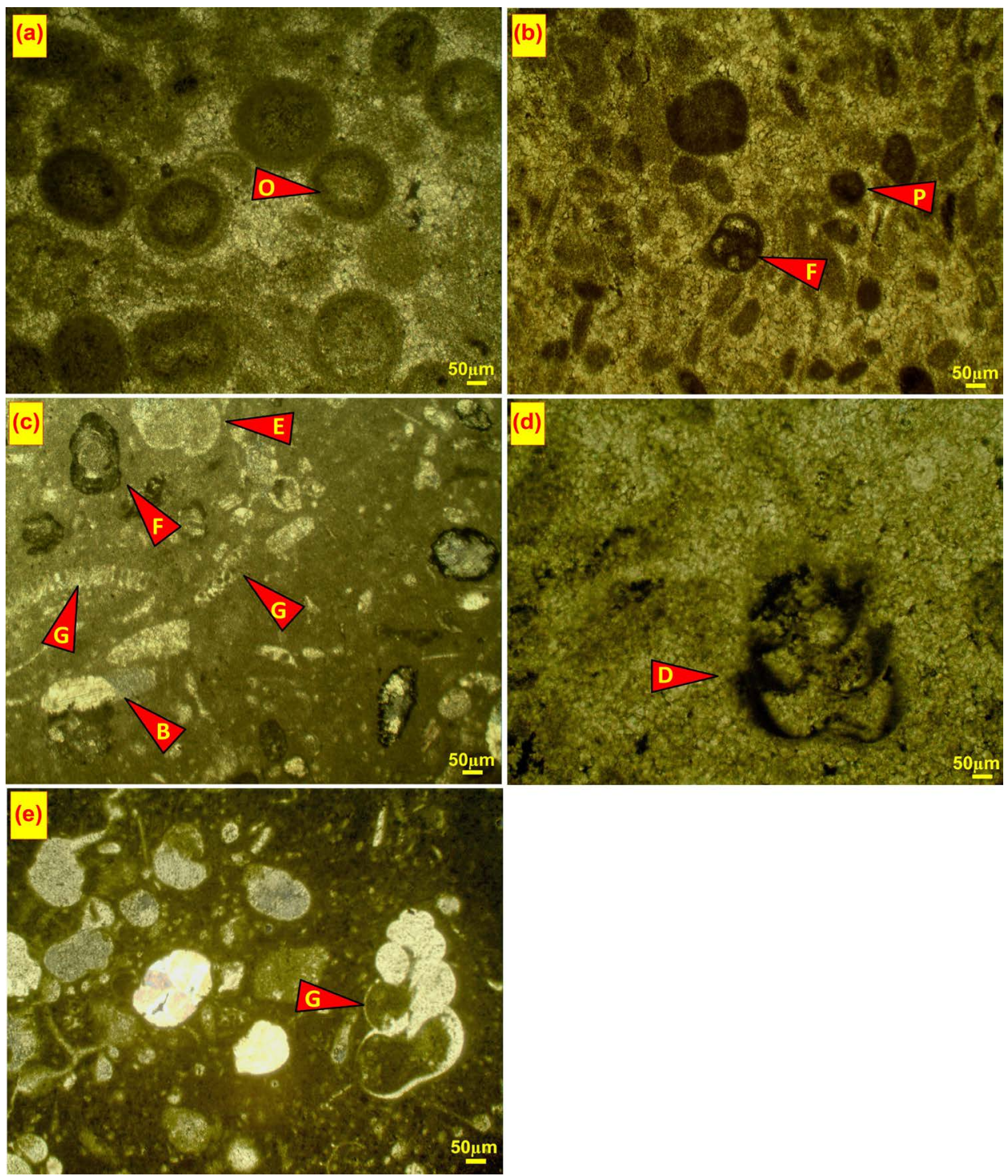

Figure 3. Lagoon Facies: (a) Ooid wackestone/packstone with micritic ooids "O"; (b) Peloid wackestone/packstone, peloids "P" are found with forams "F"; (c) Bioclast wackestone/packstone with algal and benthic foraminifera, arrows point to forams "F", gymnocodiacean algae " $G$ ", echinoderms "E" and bivalves "B"; (d) Mudstone with lagoonal foraminifera such as Dagmarita "D"; (e) Bioclast wackestone/packstone with gastropod "G" (XPL). 
ostracod fragments (Figure 3(e)). The gastropods are found in inner ramp to mid ramp settings, but associated fauna can help us to recognize the living environment of the animals. Considering the presence of dasyclads and benthic foraminifera, this facies is attributed to the back-barrier lagoon environment [3].

\subsection{Facies Association C (Shoal Facies)}

\subsubsection{Facies C1 (Bioclast Ooid Grainstone)}

This facies contains high amount of ooids associated with bryozoans. The nuclei of some ooids have been dissolved and replaced by spary cement. Oomoldic and intergranular porosity is common (Figure 4(a) and Figure 4(b)). Considering the ooid types and presence of bryozoans, this facies contemplates the high energy shoal settings [16] [18].

\subsubsection{Facies C2 (Ooid Grainstone)}

This facies comprises high amount of spherical to ellipsoid ooids sized of $250 \mu \mathrm{m}-1$ $\mathrm{mm}$ with concentric microstructure. They have been mimically replaced by dolomite. Isopachous marine cement is developed around the grains. Diagenetic process such as dolomitization and dissolution are common and have played an influential role in the reservoir characteristic (Figure 4(c)). The ooids and cement types coincides the shoal environment [16] [18].
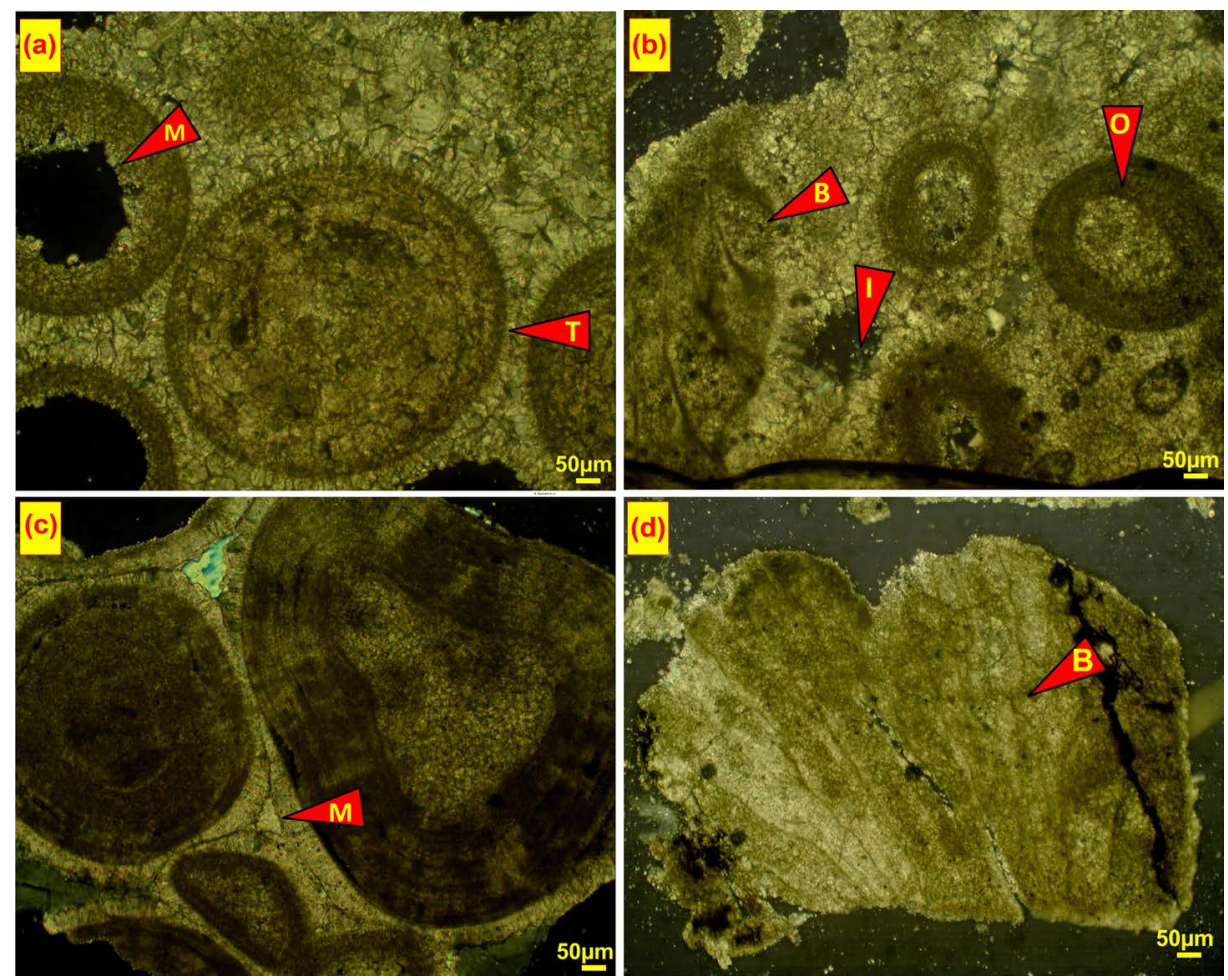

Figure 4. Shoal Facies: (a) and (b) Bioclast ooid grainstone, Tangential ooids " $T$ " with oomoldic "O" and intergranular "I" porosity accompanied with bryozoans "B"; (c) Ooid grainstone with isopachous rimmed cement " $\mathrm{M}$ "; (d) Coarse grain intraclast bioclast grainstone including whole bryozoans "B" (XPL). 


\subsubsection{Facies C3 (Coarse Grain Intraclast Bioclast Grainstone)}

The facies C3 consist of high percent intraclasts which are $250 \mu \mathrm{m}-1 \mathrm{~mm}$ and whole bryozoans accompanied with ooids and peloids carried from shoals. Intraclasts are medium sorted and rounded. The cement comprising isopachous rimmed cement, burial mosaic cement and anhydritic cement. Cementation, dolomitization and dissolution are frequent (Figure 4(d)). Lack of micrite and high percentage of intraclasts associated with bryozoans indicate seaward-shoal settings [20] [21].

\subsection{Facies Association D (Open Marine Facies)}

\section{Facies D1 (Bioclast Mudstone)}

This facies contains low percentage of spars ostracod and brachiopod fragments in the micritic matrix (Figure 5(a) and Figure 5(b)). The abundant micrite, rare skeletal fragments and scarcity of evaporites and intraclasts denotes open-marine low energy settings.

\section{Depositional Model of Middle-Late Permian Sediments in Well $\mathrm{ZH}-\mathrm{A}$}

Studies on facies associations and their lateral and vertical patterns based on depositional models, facies zones and standard microfacies reveal that the depositional model of Dalan Formation is a carbonate ramp (Figure 6). Gradual changes between relatively widespread facies belts, lack of breccias, ample skeletal particles, ooids, peloids, intraclasts and calciturbidites, presence of high energy grainstones in shoreface depositional settings accompanied by dasyclads and forams designate a homoclinal ramp setting. The cortoids, oncoids, pisoids and aggregates are rare [3]. Development of supratidal facies (A1) in the studied sequence points to the regression and arid climate resembling today's climate in Persian Gulf. The Dalan Formation formed on the passive margin of the Neo-Tethys Ocean extended from Saudi Arabia to Iran [4].

\section{Interpretation of Sedimentary Cycles}

Stratigraphically, this study is focused on the Dalan Formation in the Zireh Gas Field.
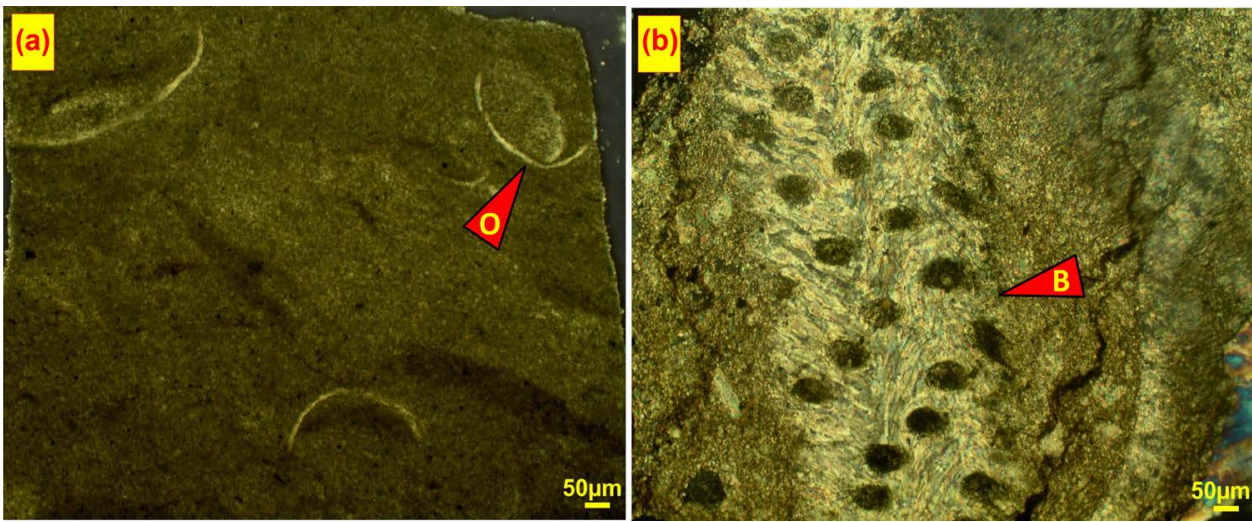

Figure 5. Open Marine Facies: (a) and (b) Bioclast mudstone, ostracods "O" and punctate brachiopod "B" fragments are outspread in the matrix (XPL). 


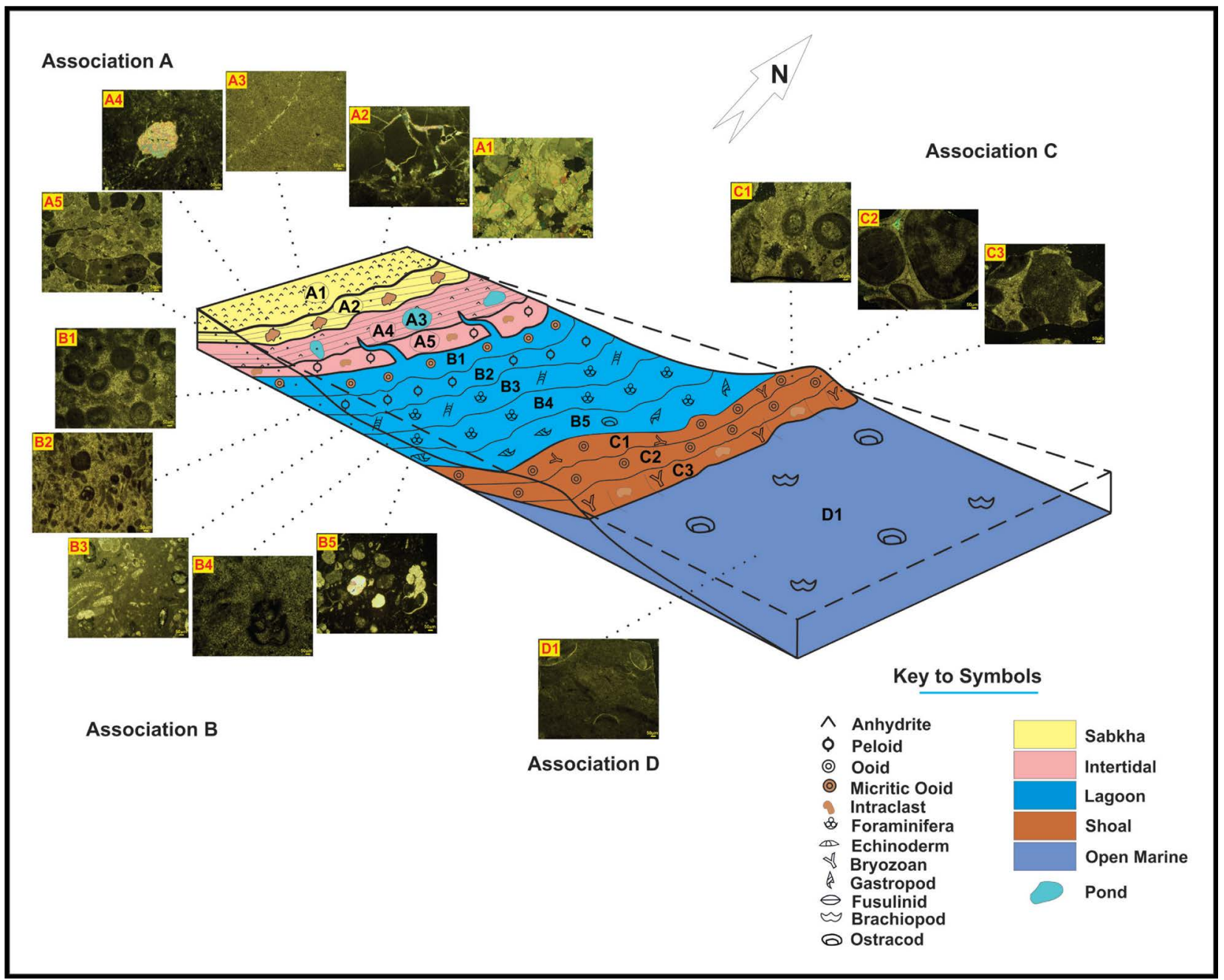

Figure 6. Depositional model of Dalan Formation in Zireh Gas Field (Well ZH-A).

The stacking pattern and depositional settings employed to interpret the depositional sequences. The sequence boundary between LDS-1 and Faraghan Sandstone is Subaerial Unconformity (SU), but the boundaries between third-order cycles and Kangan Formation are Correlative Conformity (CC) and there is no Low Stand System Tract (LST) due to stable condition on the passive margin of Neo-Tethys Ocean.

Cycle 1 (LDS-1): This cycle has been identified according to the electrical logs (Gamma-Ray) and Paleologs due to lack of samples (Figure 7). The Maximum Flooding Surface (MFS) of this unit is marked by argillaceous and shaly deposits comprising "condensed zone" (Picked by sudden increase in gamma-ray response). The lower boundary of this cycle coincides the Global Stratotype Section and Point (GSSP, CC 268 Ma) [12] and sea-level falling [8] [11]. The MFS of this cycle is according to Wor1 [8] and sea-level rising [11]. The upper boundary of this cycle would correspond to the GSSP (CC 265.8) [12] and sea-level falling [8] [11].

Cycle 2 (LDS-2): This sequence includes Middle Lower Dalan Member encompassing the middle part of $\mathrm{K} 5$ reservoir (Figure 7). TST of this unit includes lagoonal and 
shoal facies in retrogradation stacking pattern. The MFS of this unit is marked by coarse grain intraclast bioclast grainstone (C3). HST is designated by lagoonal and intertidal facies that is capped by supratidal facies (A1). The MFS of this cycle coincides to the Wor3 [8].

Cycle 3 (LDS-3): LDS-3 encompasses the upper part of K5 reservoir (Figure 7). TST comprises of intertidal facies in retrogradation stacking pattern. MFS of this unit is marked by lagoonal facies (B3). HST of this cycle which passes through the Nar member is recognized by intertidal dolomudstone with evaporite cast (A4) that is capped by supratidal evaporitic facies (A1). MFS of this cycle would correspond to the Cap1 [8] and sea-level rising [11].

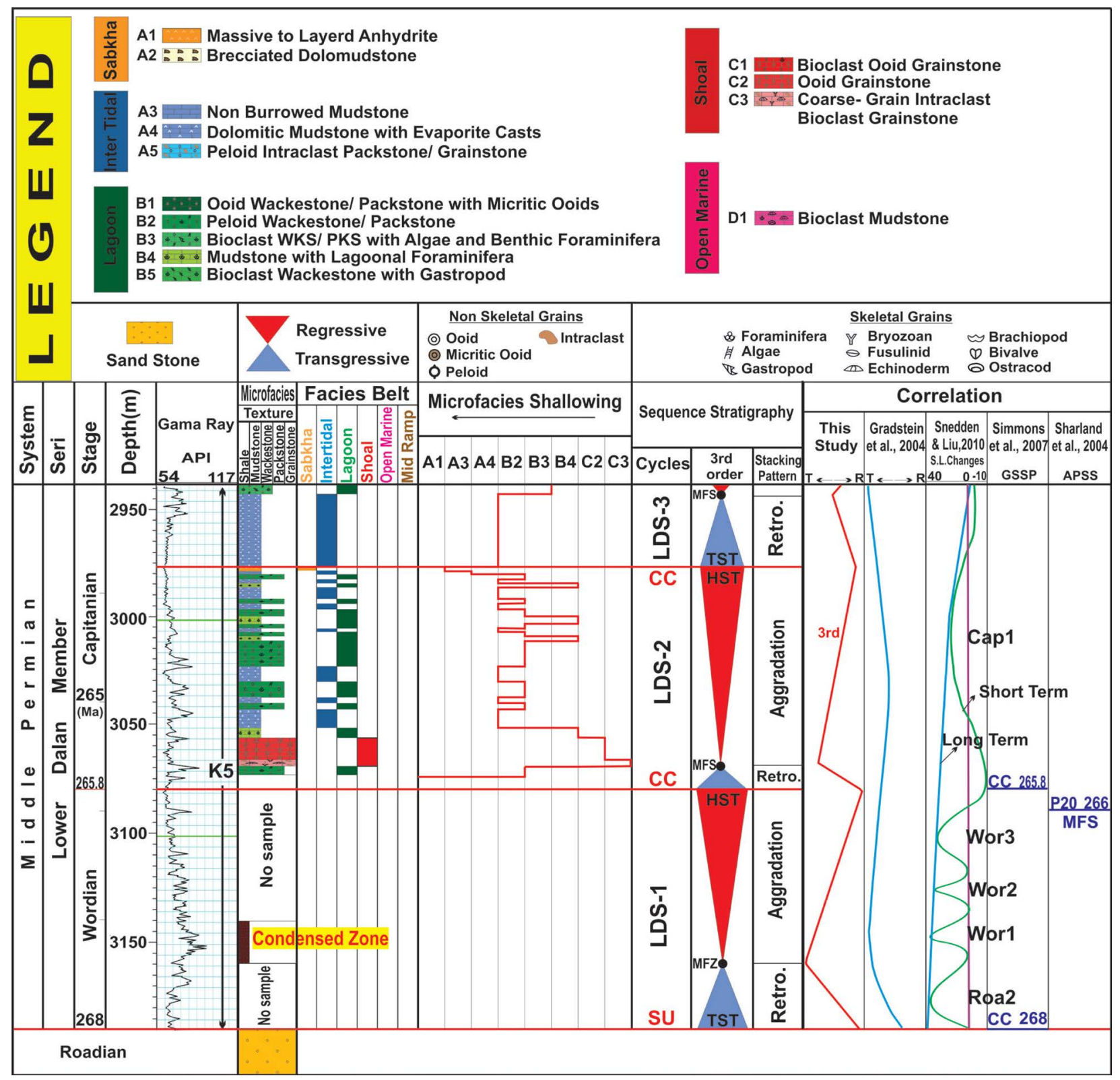

Figure 7. Lower Dalan member depositional cycles and their correlations with last calibrated sea-level changes and GSSP. 
Cycle 4 (Nar-S): This sequence includes Nar member (Figure 8). TST includes a succession of intertidal and lagoonal facies in retrogradation stacking pattern. The maximum accommodation of this unit is distinguished by ooid grainstone facies (C2). The MFS of this cycle is according to the Cap3 [8]. This cycle is characterized by global warming and sea-level falling evidenced by intertidal to supratidal evaporitic facies.

Cycle 5 (UDS-1): This cycle comprises K4 reservoir (Figure 9). TST of this sequence contains intertidal, Lagoonal and shoal facies in Retrogradation Stacking Pattern (RSP). The MFS of this unit is distinguished by Open-marine bioclast mudstone (D1). HST contains Shoal (C2), lagoonal and intertidal facies that is covered by sabkha brecciated

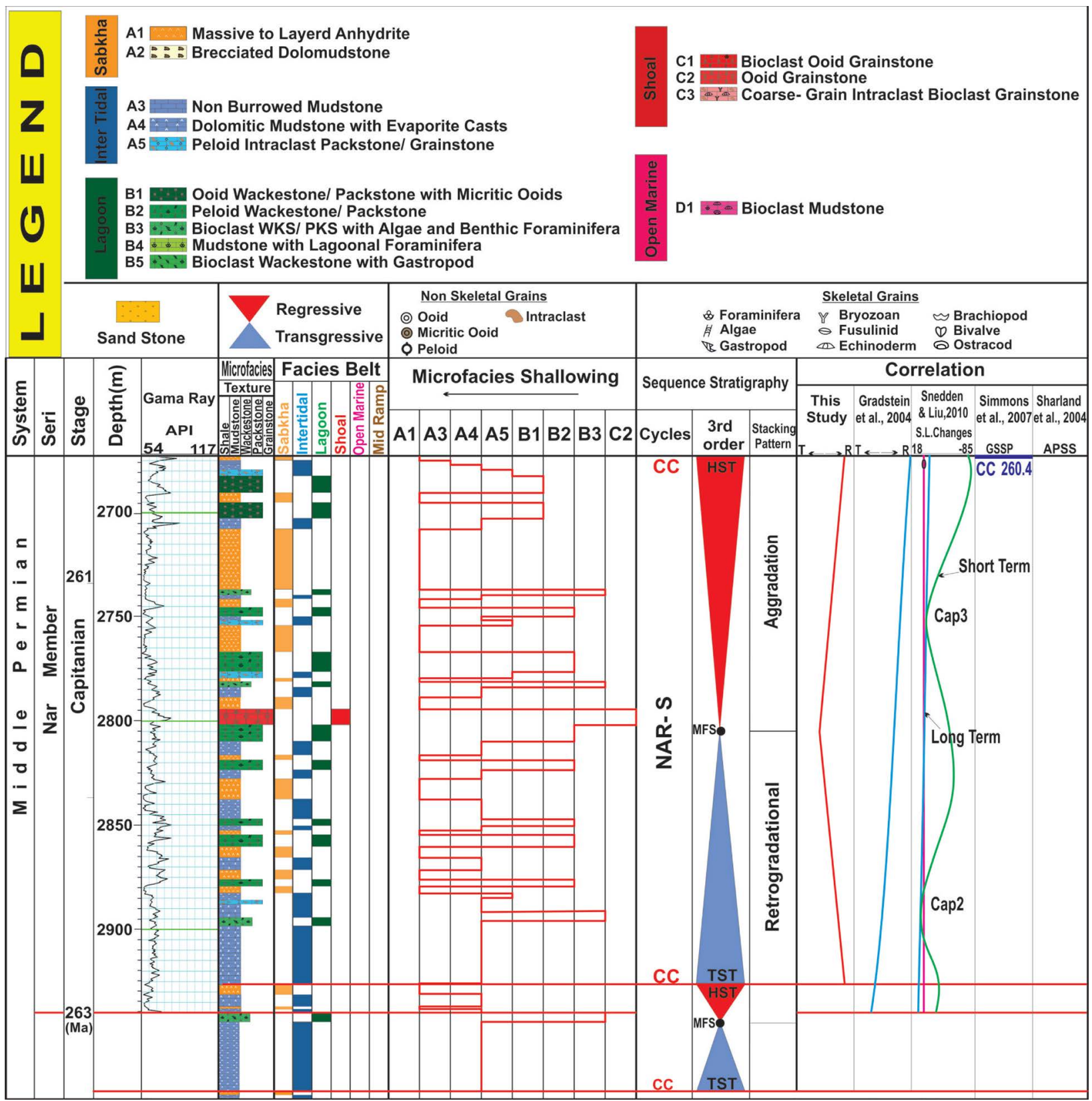

Figure 8. Nar member depositional cycles and their correlations with last calibrated sea-level changes and GSSP. 




Figure 9. Upper Dalan depositional cycles and their correlations with last calibrated sea-level changes and GSSP.

dolomudstone (A2). The Late Permian universal glaciations and melting episodes resulted local sea-level changes evidenced by abundant $4^{\text {th }}$-order cycles comprising $3^{\text {rd }}$ order depositional cycles. The MFS of UDS-1 will coincide to Wu1 [8].

Cycle 6 (UDS-2): UDS-2 comprehends upper part of K4 reservoir (Figure 9). TST 
of UDS-2 contains intertidal and lagoonal. The MFS is designated by coarse grain intraclast bioclast grainstone (C3) that is supposed to be resulted by thermal subsidence and sea-level flactuations due to global ice-house conditions [4] [22]. This cycle is covered by intertidal (A3) facies. The MFS of UDS-2 coincides to the P30 MFS [9] [10] and universal sea-level rising [11].

Cycle 7 (UDS-3): The last cycle comprises K3 reservoir (Figure 9). TST of UDS-3 includes lagoonal (B3) facies in RSP. Mudstone with lagoonal foraminifera (B4) facies denotes MFS of UDS-3. The HST is distinguished by lagoonal facies that is beetled by intertidal (A3) facies. The MFS of UDS-3 is according to P40 MFS [9] [10] and Chan2 [8]. The Permo-Triassic boundary matches to Tr10 [9] [10], CC 251 [12] and global sea-level falling [11] expressing the mass extinction at the end of Permian.

\section{Conclusions}

Based on microfacies analysis and significant founa and flora, fourteen major facies in four facies associations containing Tidal flat (A), Lagoon (B), Shoal (C) and Open-marine (D) were distinguished in the well $\mathrm{ZH}-\mathrm{A}$. Lagoon facies are frequent, but are well distributed in Upper Dalan Member. The Ooid Grainstone facies (C1) has a good reservoir potential due to intergranular and oomoldic porosity accompanied by mimic dolomitization. This facies is well developed in UDS-1 comprising K4 reservoir. The open-marine facies (D1) is established in UDS- 1.

Gradual changes between relatively widespread facies belts, lack of breccias, ample skeletal particles, ooids, peloids, intraclasts and calciturbidites, presence of high energy grainstones in shoreface depositional settings associated with dasyclads and forams designate a homoclinal carbonate ramp.

Based on depositional sequence studies, seven main $3^{\text {rd }}$ order sedimentary cycles were revealed in the Well ZH-A. The MFS of depositional cycles matches the best with the MFS proposed by Snedden and Liu [8]. Dolomitization and high evaporation are common in the late HST due to global sea-level falling. The transgressive-regressive cycles have good correlation with the last calibrated sea-level changes and GSSP.

\section{Acknowledgements}

The authors thank the experts and management of NIOC (National Iranian Oil Company) who provided financial support for this research and gave permission to publish this paper as well as Islamic Azad University, North Tehran Branch. We also express our thanks to the people whom supported us in any aspects of this research.

\section{References}

[1] Edgell, H.S. (1977) The Permian System as an Oil and Gas Reservoir in Iran, Iraq and Arabia. Proceedings of the Second Iranian Geological Symposium, 161-201.

[2] Dunham, R.J. (1962) Classification of Carbonate Rocks According to Depositional Texture. In: Ham, W.E., Ed., Classification of Carbonate Rocks, a Symposium, AAPG Mem., No. 1, 108-121.

[3] Flügel, E. (2010) Microfacies of Carbonate Rocks, Analysis, Interpretation and Application. 
Springer-Verlag, Berlin, 996 p.

[4] Insalaco, E., Virgone, A., Courme, B., Gaillot, J., Kamali, M., Moallemi, A., Lotfpour, M. and Monibi, S. (2006) Upper Dalan Member and Kangan Formation between the Zagros Mountains and Offshore Fars, Iran: Depositional System, Biostratigraphy and Stratigraphic Architecture. GeoArabia, 11, 74-176.

[5] Lasemi, Y., Jahani, D., Amin-Rasouli, H. and Lasemi, Z. (2012) Ancient Carbonate Tidalites. In: Davis, R.A. and Dalrymple, R.W., Eds., Principle of Tidal Sedimentology, Springer, 576-609.

[6] Fotovat, M., Hosseini, G.H. and Rahimpour-Bonab, H. (2012) Sedimentary Environment of Upper Dalan Member in Qatar-Fars Arch and Its Eastern Margin: South Pars and Salman Fields. Stratigraphy and Sedimentology Researches, 42, 115-136. (In Persian)

[7] Catuneanu, O., Galloway, W.E., Kendall, C.G.S.T.C., Miall, A.D., Posamentier, H.W., Strasser, A. and Tucker, M.E. (2011) Sequence Stratigraphy: Methodology and Nomenclature. Newsletters on Stratigraphy, 44, 173-245. https://doi.org/10.1127/0078-0421/2011/0011

[8] Snedden, J.W. and Liu, C. (2010) A Compilation of Phanerozoic Sea-Level Change, Coastal Onlaps and Recommended Sequence Designation. Search and Discovery Article 40594, AAPG.

[9] Sharland, P.R., Archer, R., Casey, D.M., Davies, R.B., Hall, S.H., Heward, A.P., Hourbury, A.D. and Simmons, M.D. (2001) Arabian Plate Sequence Stratigraphy. GeoArabia Special Publication 2, Gulf PetroLink, 371 p.

[10] Sharland, P.R., Casey, D.M., Davies, R.B., Simmons, M.D. and Sutcliffe, O.E. (2004) Arabian Plate Sequence Stratigraphy. GeoArabia, 9, 199-214.

[11] Gradstein, F.M., Ogg, J.C. and Smith, A.G. (2004) A Geological Time Scale. Cambridge University Press, New York.

[12] Simmons, M.D., Sharland, P.R., Casey, D.M., Davies, R.B. and Sutcliffe, O.E. (2007) Arabian Plate Sequence Stratigraphy: Potential Implications for Global Chronostratigraphy. GeoArabia, 12, 101-130.

[13] Warren, J.K. (2006) Evaporites: Sediments, Resources and Hydrocarbons. Springer Verlag, New York, 1041 p. https://doi.org/10.1007/3-540-32344-9

[14] Teymourzadeh, H., Vaziri, S.H., Jahani, D., Kohansal Ghadimvand, N. and Yahyaei, A. (2014) Exploration Characteristics and Lithostratigraphy of the Kangan and Upper Dalan Formations in Lavan Gas Field, Northen Persian Gulf. Academic Research Part A, 6, 311320.

[15] Zamannejad, A., Jahani, D., Lotfpour, M. and Movahed, B. (2013) Mixed Evaporite/Carbonate Characteristics of the Triassic Kangan Formation, Offshore Area, Persian Gulf. Revista Mexicana de Ciencias Geológicas, 30, 540-551.

[16] Strasser, A. (1984) Black-Pebble Occurrence and Genesis in Holocene Carbonate Sediments (Florida Keys, Bahamas and Tunisia). Journal of Sedimentary Petrology, 54, 1097-1109. https://doi.org/10.1306/212f856c-2b24-11d7-8648000102c1865d

[17] Tucker, M.E. and Wright, V.P. (1990) Carbonate Sedimentology. Blackwell Publishing Company, Cornwall. https://doi.org/10.1002/9781444314175

[18] Steinhoff, I. and Strohmenger, C. (1996) Zechstein 2 Carbonate Platform Subfacies and Grain-Type Distribution (Upper Permian, Northwest Germany). Facies, 35, 105-132. https://doi.org/10.1007/BF02536959

[19] Madi, A., Savard, M.M., Bourque, P.A. and Chi, G. (2000) Hydrocarbon Potential of the Mississippian Carbonate Platform, Bechar Basin. Algerian Sahara, 84, 266-287. 
[20] Madi, A., Bourque, P.A. and Mamet, B.I. (1996) Depth-Related Ecological Zonation of a Carboniferous Carbonate Ramp: Upper Viséan of Béchar Basin, Western Algeria. Facies, 35, 59-80. https://doi.org/10.1007/BF02536957

[21] Rezavand, N., Jahani, D. and Asilian, H. (2016) Facies, Sedimentary Environment and Sequence Stratigraphy of Dalan Formation in South Fars, Iran. Open Journal of Geology, 6, 944-962. https://doi.org/10.4236/ojg.2016.68071

[22] Angiolini, L., Balini, M., Garzanti, E., Nicora, A., Tintori, A., Crasquin, S. and Muttoni, G. (2003) Permian Climatic and Paleogeographic Changes in Northern Gondwana: The Khuff Formation of Interior Oman. Palaeogeography, Palaeoclimatology, Palaeoecology, 191, 269-300. https://doi.org/10.1016/S0031-0182(02)00668-5

Submit or recommend next manuscript to SCIRP and we will provide best service for you:

Accepting pre-submission inquiries through Email, Facebook, LinkedIn, Twitter, etc. A wide selection of journals (inclusive of 9 subjects, more than 200 journals)

Providing 24-hour high-quality service

User-friendly online submission system

Fair and swift peer-review system

Efficient typesetting and proofreading procedure

Display of the result of downloads and visits, as well as the number of cited articles

Maximum dissemination of your research work

Submit your manuscript at: http://papersubmission.scirp.org/

Or contact ojg@scirp.org 